Original Research Paper

\title{
Effect of Different Cycles of Thermal Fatigue in Steel Metallurgical Aspects ASTM SA-516 Grade 60
}

\author{
${ }^{1}$ Eder Hermes Bicharra, ${ }^{1}$ Jorge Luis Braz Medeiros, ${ }^{1}$ Luciano Volcanoglo Biehl, \\ ${ }^{1}$ Eduardo da Rosa Vieira, ${ }^{1}$ Maurício Diogo da Silva, ${ }^{2}$ José de Souza and ${ }^{3}$ Carlos Otávio Damas Martins \\ ${ }^{1}$ Universidade Federal do Rio Grande - FURG, Rio Grande, Brazil \\ ${ }^{2}$ Fundação Liberato, Novo Hamburgo, Brazil \\ ${ }^{3}$ Universidade Federal de Sergipe - UFS, Brazil
}

Article history

Received: 03-07-2020

Revised: 13-08-2020

Accepted: 27-08-2020

Corresponding Author:

José de Souza

Fundação Liberato, Novo

Hamburgo, Brazil

Email: josesouza@liberato.com.br

\begin{abstract}
The ASTM SA-516 steel has applications in compact steam boilers of low and medium temperature and pressure. Deterioration can show when exposed to high temperatures due to fuel gases burning. Failures detected by inspections done in a frequency required by standard on the boilers. Among the main failure mechanisms found in materials used in boilers, creep, corrosion, when subjected to the action of the combustion gases or steam oxidation conditions, thermal fatigue and others can be mentioned. This work evaluates the effect of thermal fatigue in the metallurgical aspects of steel ASTM SA-516 grade 60. After the initial characterization of the steel checked that it heeds the specifications required by the standard, showing a microstructure of ferrite and perlite. The tests in heat transfer conditions produce temperatures between 750 to $850^{\circ} \mathrm{C}$ on the surface, starting with an oxidizing flame produced by oxygen and acetylene gases. The cooling was by water, being the samples were submitted to several cycles of heating and cooling, causing thermal fatigue. After the tests, occurs the characterized of the samples through optical microscopy techniques, Scanning Electronic Microscopy (SEM), Energy Dispersive Spectroscopy (EDS), Vickers hardness and macrostructure analysis. ferrite, perlite colonies and no tempered martensite were the microstructures detected on the Heat-Affected Zone (HAZ). On substrate's region was not detected anisotropy or significant variations. When analyzing austenitic grain size was observed a refinement showing 12 ASTM grain size considered extra fine. The higher microhardness values occurred at the surface. The surface has had been affected by heat due to heating in intercritical and austenitization temperature and the cooling by water.
\end{abstract}

Keywords: Boilers, ASTM SA-516 Grade 60, Thermal Fatigue, Thermal Fatigue Test, Metallurgical Aspects

\section{Introduction}

In thick smoke tube boilers characterized by furnaces located in the inside the surface, the circulation of the combustion gases takes place inside the tubes of the tube beam until the outlet through the chimney. SA-516 grade 60 steel is used in pressure vessels and boilers for medium and low service temperatures. This steel has tensile strength between 415 to $550 \mathrm{MPa}$, low carbon content $(\leq 0.21 \%)$ and with elements in its chemical composition that stand out, such as Manganese (0.55-0.98\%) and Silicon (0.13-0.45\%), the metallurgical structure of this steel, which assesses the austenitic grain size, must have a larger grain size equal to number 5 (ASTM 2004). The typical structure of low carbon steel consists of ferrite and perlite's grains, with equal dimensions in all directions of the structure. The microstructure that contains ferrite and perlite with a low content of inclusions is typical for low carbon steel used in boilers (Gong et al., 2010), (Duarte et al., 2017).

Boilers after a certain period of use, which can be continuous or intermittent, are subject to some varieties of failures, involving one or more mechanisms, among the leading causes in the 
materials can mention creep, corrosion when subjected to the action of combustion and vapor oxidation conditions, thermal fatigue and others (Viswanathan and Bakker, 2001; Masuyama, 2001).

After analyzing the microstructure in samples from the broken boiler tube, which has chemical elements and microstructure similar to that of SA - 516 steel, it could be observed that the microstructural changes that occurred in the material led to the formation of a mixed martensite and bainite microstructure (Masuyama, 2001). These phases formed by exposure of steel to high temperatures due to combustion gases, followed by rapid natural cooling, similar to tempering heat treatment (Barbosa et al., 2012). Thermal fatigue and creep are among the leading causes of failures in boiler components because of the tremendous thermal stress that arises when the equipment starts operating and after its use is turned off (Kumar et al., 2016). When subjected to thermal fatigue, components can suffer unacceptable geometric deformations and changes in their properties (Da Silva et al., 2011).

When it comes to thermal equipment, it is relevant to analyze the effect of temperature on the metallurgical and mechanical properties of low-alloy steels applied to the boiler, an example of such equipment. The mechanical and metallurgical properties on the effect of temperatures to the heat treatment processes, sometimes required to improve these, via modification of the microstructure of the steels (Liu et al., 2016).

When submitting the samples in the tempering and tempering heat treatments in low alloy steel, to verify the effect of the temperature of $920^{\circ} \mathrm{C}$ on the microstructure, the heat treatments applied promoted a significant grain refining in the steel structure. Some properties of SA-516 steel, on the microstructure in the zone affected by heat (HAZ), equiaxial ferrite grains and small pearlite colonies, occurs. With grains considerably refined, due to the partial transformation of austenite within the intercritical temperature region, between $A_{1}$ and $A_{3}$, the material has been exposed to this region for insufficient time for a complete transformation of austenite, leading to the formation of perlite colonies on ferrite, during cooling (Araújo et al., 2015; Lim et al., 2016).

When heating an SA-516 steel of initial microstructure composed of ferrite/perlite to a temperature of $1100^{\circ} \mathrm{C}$, followed by two cycles of heat annealing at a temperature of $750^{\circ} \mathrm{C}$ for $30 \mathrm{~min}$, followed by a cooling in water until the temperature environment, a final microstructure composed of ferrite/martensite is achieved (Shahzad et al., 2018).

Higher values of microhardness happen in the HAZ, due to the grain refining and the change of the microstructure, consequently, improving the mechanical property compared to the substrate cooling (Lim et al., 2016).
The cooling rate in steels applied in boilers, rapid cooling influences the mechanical properties of ASTM SA-516 steel. A reduction in the size of the ferritic grain was verified, with possible formation of bainite and increased hardness in the steel. For steels with a low content of alloy elements, consequently, their carbon equivalent is lower, with a lower cooling rate, more ferrite and bainite formed (Barbosa Junior, 2007). An increase in carbon equivalent happens by the increase in the amount of martensite in its microstructure for a high cooling rate. ASTM SA-516 steels, where high cooling speeds occur for temperature variations between 800 and $500^{\circ} \mathrm{C}$ in less than $9.0 \mathrm{sec}$, structures with higher hardness can be formed (Zhang et al., 2006; Ribeiro, 2001).

When submitting ferrous alloys to thermal fatigue, it is possible to verify the effect of this condition for the materials, the microstructure of the H13 steel after the thermal fatigue cycles and formed a thin layer of oxides on the surface. In an alloy of steel with a high Mn content where the initial microstructure consists of austenite and perlite in polygonal and equiaxial grains, after the first cycles of thermal fatigue, some islands of pearlite presented, as the number of perlite colonies increases. Its microstructure corresponds to a pearlitic structure. In H13 steel, its martensitic microstructure is progressively enveloped by a mixture of ferrites and carbides as the number of cycles of thermal fatigue increases, after 3000 cycles, the structure is entirely involved (Mellouli et al., 2014; Roa et al., 2016; Li et al., 2018).

Based on the above, the objective of the work is to verify the metallurgical aspects in the region of steel ASTM SA-516 grade 60 submitted to the thermal fatigue test with different cycles and to analyze the mechanical property of Vickers microhardness in the region of the steel subjected to the test. Moreover, compare the results between the different cycles and with the material as received. The tests occurred with equipment developed particularly for this tests and the samples heated until reaching temperatures between 750 to $850^{\circ} \mathrm{C}$, aided by oxyacetylene flame and the cooling was given by water until reaching temperatures between 20 to $25^{\circ} \mathrm{C}$, were samples submitted to 250,500 and 750 thermal fatigue cycles were evaluated.

\section{Materials and Methods}

\section{Characteristics of SA Steel-516 Grade 60}

A sample of SA-516 grade 60 steel as received (CR) used to perform an initial characterization of this material consists of evaluating some properties such as chemical composition, microstructure, Vickers microhardness, austenitic grain size and tensile strength. The chemical composition of the material was obtained, shown in Table 1. 
Table 1: Table type styles (Table caption is indispensable).

\begin{tabular}{|c|c|c|c|c|c|c|c|c|c|c|}
\hline $\mathrm{C}$ & $\mathrm{Mn}$ & $\mathrm{P}$ & $S$ & $\mathrm{Si}$ & $\mathrm{Ni}$ & $\mathrm{Cr}$ & $\mathrm{Al}$ & $\mathrm{Cu}$ & Mo & $\mathrm{C}_{\mathrm{eq}}$ \\
\hline 0.19 & 0.75 & 0.01 & 0.01 & 0.35 & 0.007 & 0.013 & 0.062 & 0.014 & 0.002 & 0.375 \\
\hline
\end{tabular}

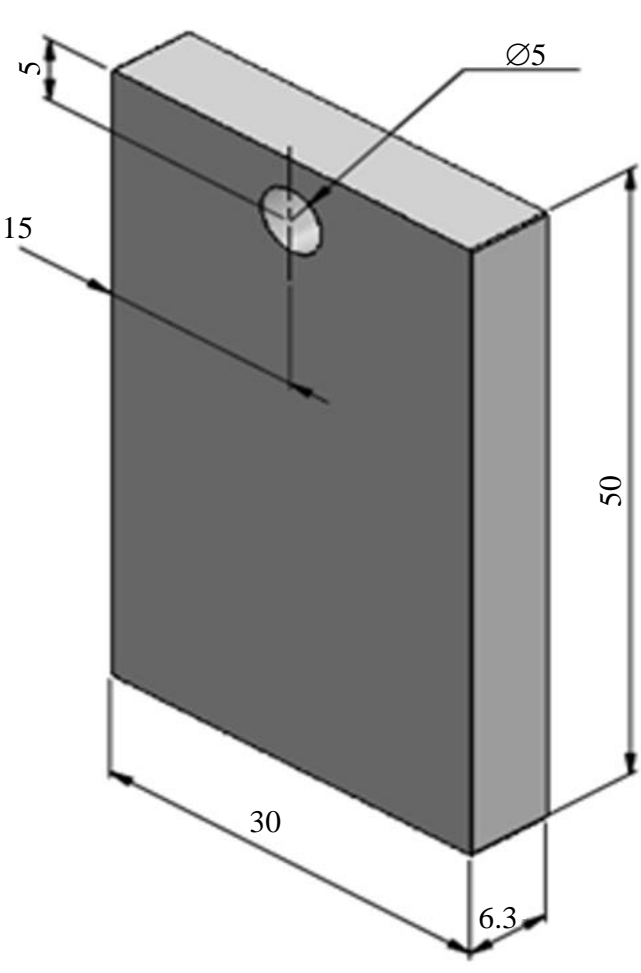

Fig. 1: Schematic drawing of the sample (mm)

The microstructure of SA-516 grade 60 steel contained ferrite and perlite phases. This microstructure being typical of hypo eutectoid steels (Gong et al., 2010; Lim et al., 2016). The ASTM grain size in the sample as received, using the grain count by the intercept method. The austenitic grain size is 5 ASTM or greater and tensile strength value of $486 \mathrm{MPa}$. This limit can differ from 415 to 550 MPa (ASTM, 2004). Its Vickers microhardness found in the studied steel characterization has a value of approximately $159 \mathrm{HV}$.

\section{Geometry of the Samples}

The development of the sample for the thermal fatigue test required a foundation in the most recent research. The authors developed the samples according to the need for the test. The use of a sample to verify the resistance to a surface's thermal fatigue occurs (Cong et al., 2014).

For this research, the sample developed to meet thermal failure tests' needs where the surface exposed to such condition was necessary to take advantage of the dimensions. Among the samples cited in the literature, the model that (Cong et al. 2014) most met the need for research was, so a similar sample was developed, in Fig. 1 , illustrating a schematic drawing with geometry and dimensions in millimeters of the samples.

\section{Thermal Fatigue Test}

To perform the thermal fatigue test was necessary to develop equipment. With support in the literature, where a machine to perform thermal fatigue tests with the working principle that consists of flame heating and water cooling (Brandim et al., 2009). The heat reached temperatures between 750 to $850^{\circ} \mathrm{C}$, aided by oxyacetylene flame. The cooling was done by water until reaching temperatures between 20 to $25^{\circ} \mathrm{C}$.

This thermal fatigue test occurs with four samples. Two of them were heating. Another two were being cooled. After reaching the programmed time of $60 \mathrm{sec}$, the two samples located in the heating station reach the maximum temperature level, the stepper motor received the electrical signal. It rotated $1 / 4$ revolution counterclockwise, causing the samples to a position at $90^{\circ}$. Hence, the two samples in the heating station pass to the cooling station, thus cooling them until they reach a temperature of 20 to $25^{\circ} \mathrm{C}$.

The samples that were in the cooling station are positioned in the heating station after the time again enters $60 \mathrm{sec}$, the stepper motor rotates $1 / 4$ revolution clockwise, thus completing a cycle. The number of cycles used in this study was 250,500 and 750 cycles. The detail of the operation of the thermal fatigue test is illustrated in Fig. 2.

Figure 3 and 4 illustrates in a particular and simplified way the moment when the reference test body reached the maximum temperature level positioned in the cooling station. Figure 3a shows the direction of rotation that the reference sample will move, Fig. $3 b$ and $3 \mathrm{c}$ shows the middle path between the stations when the body positioned in the cooling station. The test sample is cooled to the programmed time, completing a cycle, then the reference sample returns to the heating station, as shown in Fig. 3d.

For analysis of the microstructure, it occurs the attack of the sample with Nital 3\%. Later obtained the microstructure images through optical microscopy, the OLYMPUS GX 51S optical microscope and the scanning electron microscope of the JEOL model JSM$6610 \mathrm{LV}$, with a voltage of $15 \mathrm{kV}$, an analysis by EDS was carried out together. 
a)

c)

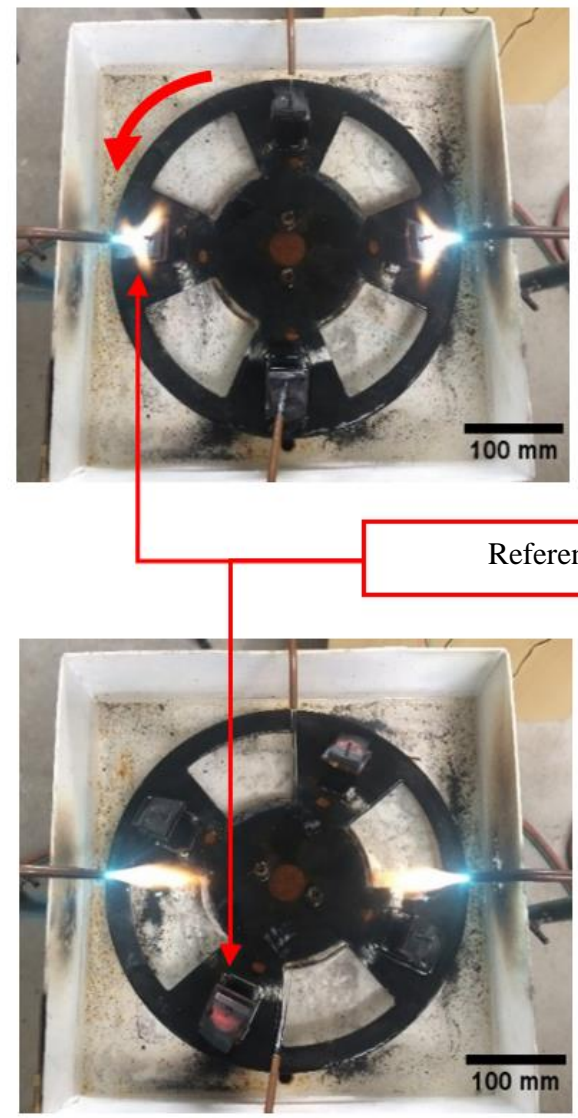

b)

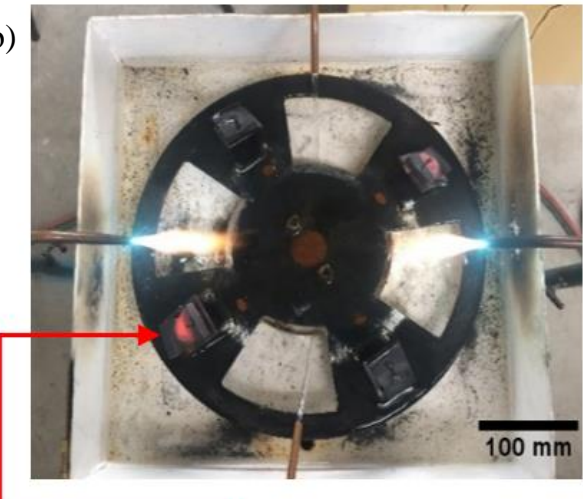

d)

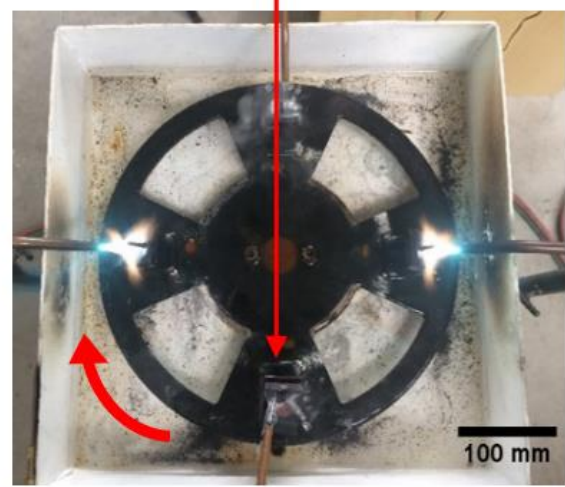

Fig. 2: Detail of the thermal fatigue test

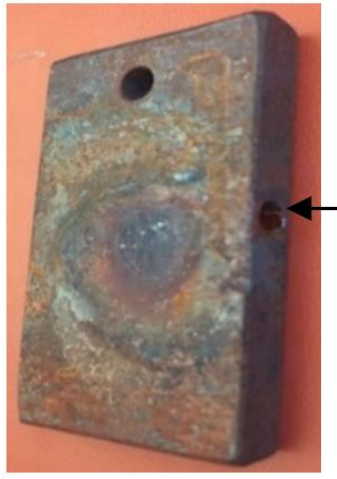

a)

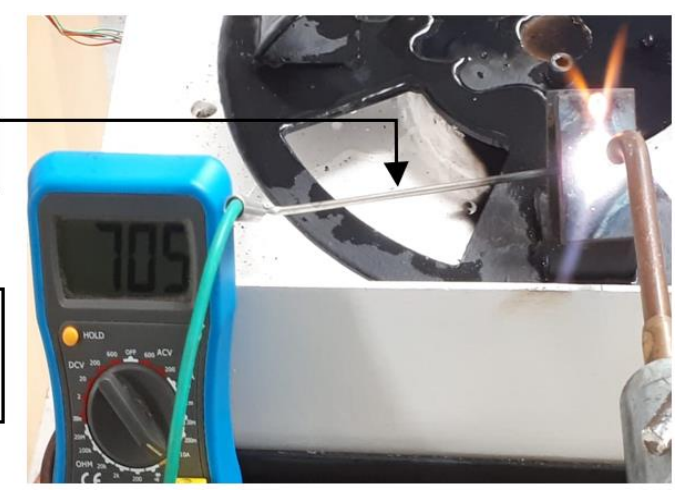

b)

Fig. 3: Detail of instruments for measuring temperature. (a) Sample with a hole. (b) An aspect of the multimeter and temperature measurement

The Vickers microhardness test occurs with the using oh Shimatzu equipment, model HMV-2T. The analysis happens with a load of $0.2 \mathrm{~kg}$ and with a time of $10 \mathrm{sec}$ for each indentation. In the transversal and longitudinal sections of the sample, 30 points befall. Divided into three columns of 10 points, spaced one millimeter between each, starting from the sample surface to the nucleus. The first point occurs at $0.15 \mathrm{~mm}$ from the surface and the other locations with $0.3 \mathrm{~mm}$ spacing between them to the nucleus of focus for better visualization (Fig. 5).

The same procedures and equipment for analyzing microstructure, using optical microscopy and Vickers microhardness, are also used to characterize the material received from ASTM SA-516 grade 60 steel. 


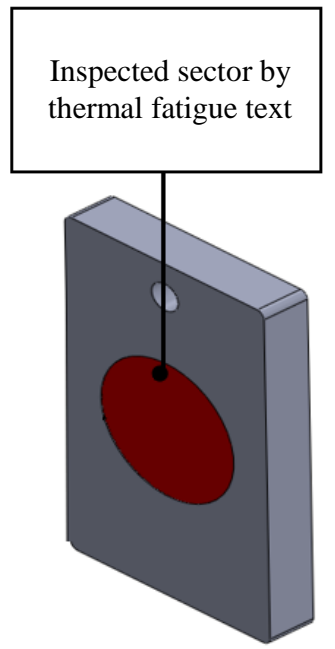

a)

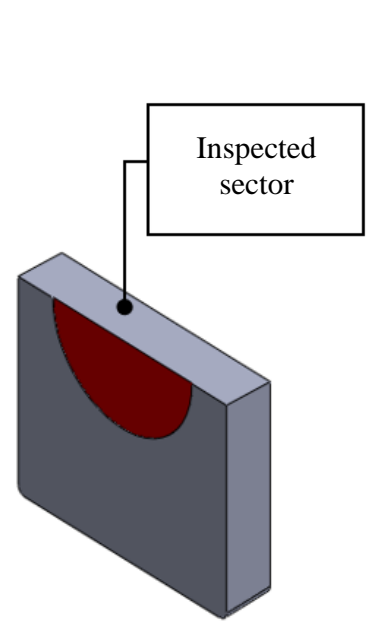

b)

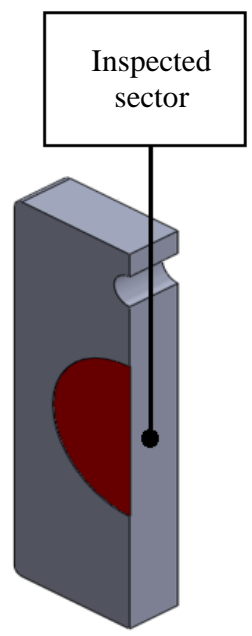

c)

Fig. 4: Detail of the samples taken after the thermal fatigue test. (a) Schematic drawing of the sample after the thermal fatigue test. (b) Schematic drawing of the cross-section taken from the sample and the detail of the analyzed region. (c) Schematic drawing of the longitudinal section taken from the sample and the aspect of the analyzed sector

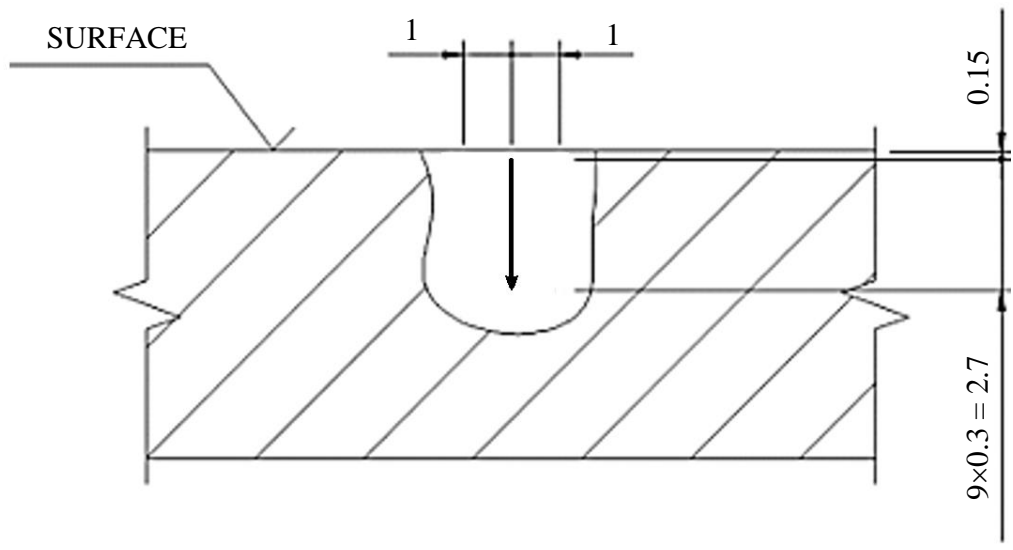

Fig. 5: Schematic drawing of the location of the points in the sample for Vickers microhardness

\section{Results}

The results obtained in the initial characterization are of paramount importance and ensured that ASTM SA 516 grade 60 steel met the required requirements. Favorable to the research, thus, through these, one can compare the effect of the thermal fatigue test on the microstructure, ASTM grain size and Vickers microhardness. After testing, the samples of the different thermal fatigue cycles analyzed to check ASTM grain size when applying the grain counting method by the intercept method. The result was austenitic grain size, the number 12 ASTM, considered as extra-fine grains, thermal treatments promoted significant grain refining in the steel structure cooling (Araújo et al., 2015).

Figure 6 illustrates the comparison of the microstructure of ASTM SA-516 grade 60 steel.
Figure 6a shows its microstructure without any thermal fatigue test. When comparing the microstructures of the samples, in the first 250 cycles of thermal fatigue, as shown in Fig. 6b, the predominance of the islands of pearlite happened (Roa et al., 2016).

The steel microstructure indicated that in a section close to the sample surface, the first layer of well-refined grains occurs. A thicker layer with pearlite islands appears in the sample subjected to 500 cycles, illustrated in Fig. 6c. In the sample subjected to 750 cycles of thermal fatigue, a first white layer occurs with a layer of well-refined grains and the pearlite islands are more agglutinated (Fig. 6d. The use of different magnifications to better visualize the modification of the microstructures was necessary.

With the use of EDS, it was possible to analyze the composition of the elements in the islands of pearlite, 
even though qualitatively we could observe the presence of the base elements of this steel, Fe, Mn and $\mathrm{C}$ and the presence of $\mathrm{O}$, as illustrated in Fig. 7.

EDS of the Perlita islands did not identify the presence of alloying elements that could "anchor" the austenitic grain size, or that could minimize the effect of diffusional transformations in the steel (Cozza et al., 2019). The residence time at high temperatures, followed by differences in cooling rates, can cause significant microstructural changes (Moojen et al., 2015). It also verified in this region the presence of tempered martensite of medium carbon, martensite will most likely be self-tempering, because it formed at high temperatures, allowing a partial tempering in the continuation of the cooling thus verified with the test of microhardness (Cozza et al., 2019).

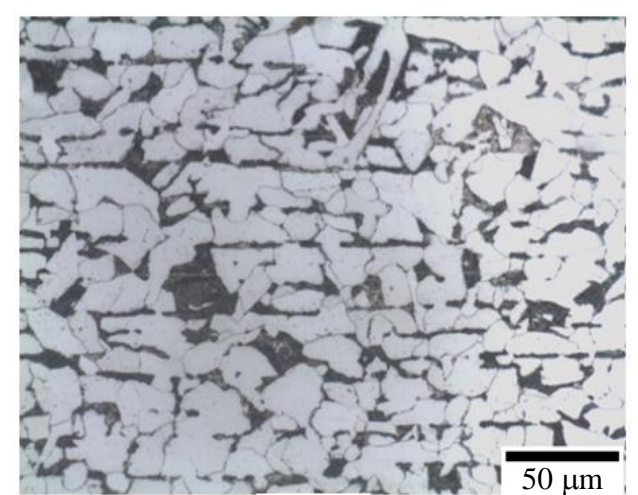

a)

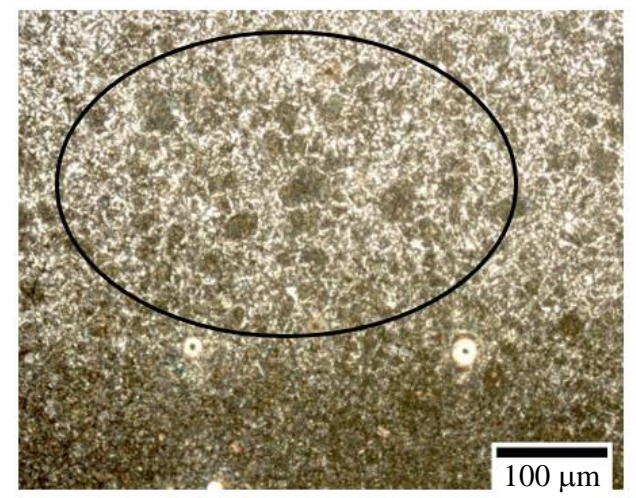

c)

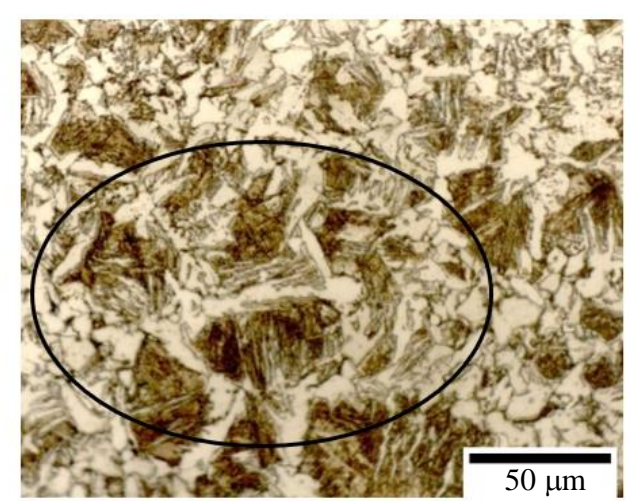

b)

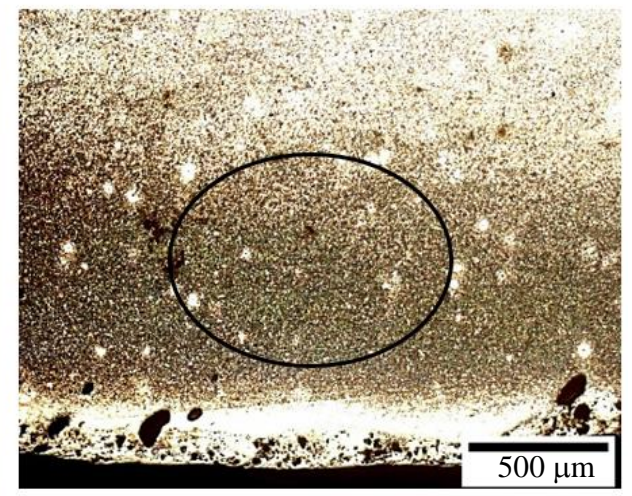

d)

Fig. 6: Microstructure steel ASTM SA 516 grade 60. (a) Steel sample as received; (b) Steel sample after 250 cycles of thermal fatigue. (c) Steel sample after 500 cycles of thermal fatigue. (d) Steel sample after 750 cycles of thermal fatigue

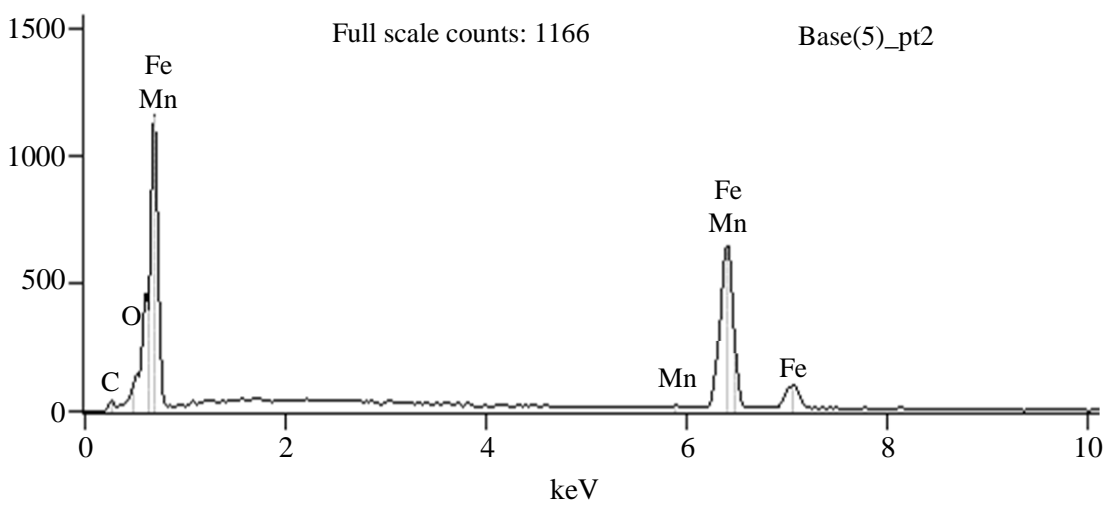

Fig. 7: EDS of the pearlite islands of the samples submitted to thermal fatigue cycles $(250,500$ and 750 cycles) 


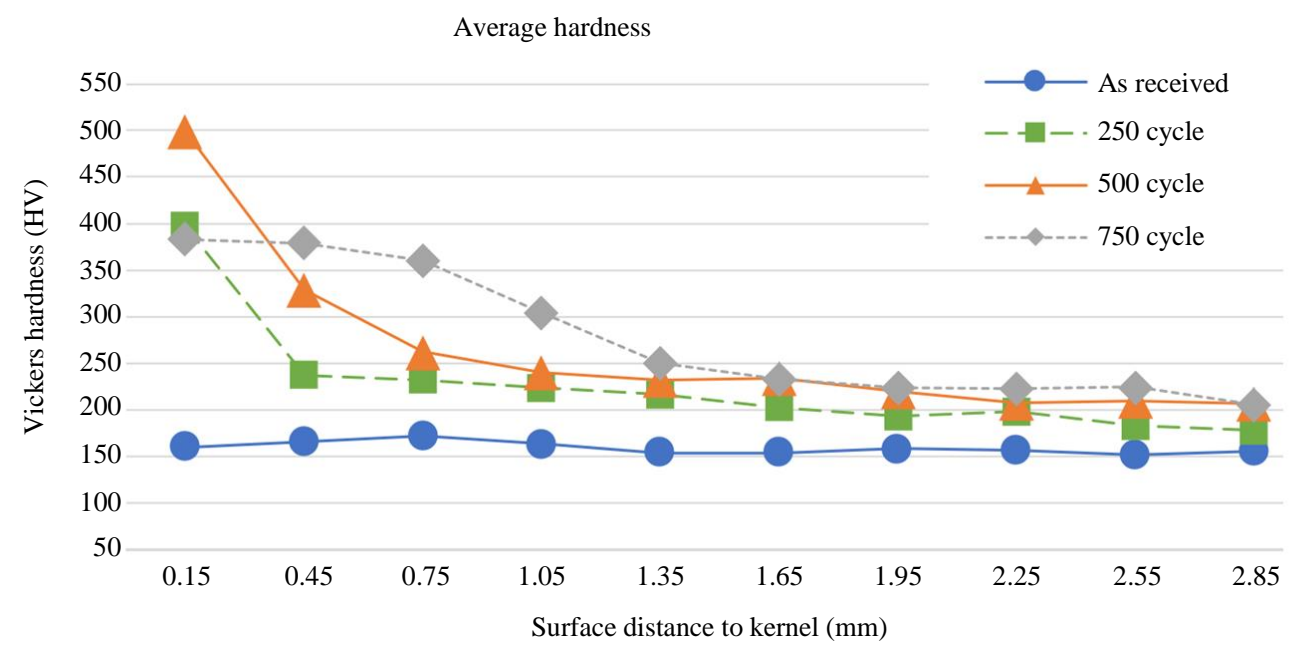

Fig. 8: Comparison of Vickers microhardness profiles, as received, 250, 500 and 750 cycles

Table 2: Average Vickers microhardness values

\begin{tabular}{ll}
\hline Sample & Vickers Hardness (HV) \\
\hline As received & 158.92 \\
250 cycles & 226.10 \\
500 cycles & 263.80 \\
750 cycles & 278.53 \\
\hline
\end{tabular}

After the survey of the average values and the Vickers microhardness profiles in the samples of the material as received and in the samples submitted to 250, 500 and 750 cycles of thermal fatigue, it was necessary a summary comparing the results of the samples to investigate the hardness of the samples after different cycles of thermal fatigue a graph was plotted (Li et al., 2018). Table 2 shows a comparison of the average Vickers microhardness values for each condition of the sample.

When evaluating the average values of microhardness found in the different conditions of the sample (Table 2), an increase in the values occurs as the thermal fatigue cycle increases. A microhardness profile was drawn for better visualization, comparing the samples of the material as received and those of different thermal fatigue cycles, shown in Fig. 8.

When comparing the microhardness values, higher values occur on the surface. At the point $0.15 \mathrm{~mm}$ from the surface, higher values were found for 250 and 500 cycles, $397 \mathrm{HV}$ and $500 \mathrm{HV}$, respectively. For such high values, it may have occurred the indentation in some non-tempered martensite present in all the samples analyzed in its microstructure, for 750 cycles found the value of $383 \mathrm{HV}$, in the other points there was a reduction of the values, approaching the material values as received. It was found that after the application of 500 and 750 cycles there was a dynamic recovery that contributed to the microstructural refining and increase of microhardness between 0.15 and $1.65 \mathrm{~mm}$ (Cozza et al., 2019). Higher values of microhardness appear in the HAZ, due to the grain refining and the change in the microstructure (Lim et al., 2016; Cozza et al., 2018). The thermal fatigue test showed an increase in microhardness compared to the material as received, as the number of cycles increases, the microhardness increases (Roa et al., 2016). Another factor that may have contributed to the increase in hardness was the cooling rate in the test. The hardness increases according to the cooling rate increases (Zhang et al., 2006; Cozza et al., 2019). High cooling speeds for temperature variation between 800 and $500^{\circ} \mathrm{C}$ in less than $9.0 \mathrm{sec}$, with higher hardness, can be formed (Ribeiro, 2001).

\section{Conclusion}

This work evaluated the metallurgical aspects of ASTM SA-516 Gr 60 steel subjected to thermal fatigue, steel commonly used in the manufacture of boilers, after tests in different thermal fatigue cycles, evaluated the results of each cycle and compared them with each other and with the material without being subjected to such an analysis, so it is possible to conclude. After the thermal fatigue cycles, the metallurgical aspects and the samples' mechanical properties, where he verified a transformation in his microstructure, pearlite colonies' presence was detected and next to the non-tempered martensite surface. In all regions, there was dynamic recovery, followed by recrystallization resulting in 12 ASTM austenitic grain size, considered extra fine grains, compared to the substrate, there is a grain refining.

There was an increase in hardness for the samples submitted to thermal fatigue cycles than the substrate, where the highest values of microhardness occurred on the surface affected by the test, due to the heating in the 
intercritical zone austenitization and the sudden cooling with water giving rise to Marten and more to the core of the sample, the values are close to that of the substrate.

\section{Funding Information}

The authors appreciate the Steammaster Indústria de Caldeiras company for donating the ASTM AS - 516 grade 60 steel for the research and the Metallography Laboratory and the technicians of CEME - SUL of the Universidade Federal de Rio Grande - FURG, who granted the equipment and necessary assistance to carry out the metallographic analyzes. Thanks to CAPES for their financial support.

\section{Author's Contributions}

Eder Hermes Bicharra: Investigation, experiments and technical procedures.

Jorge Luis Braz Medeiros: Methodological planning and organization. Formal Analysis and coordination.

Luciano Volcanoglo Biehl: Conceptualization, Methodology and Supervision.

Eduardo da Rosa Vieira: Research Data and Resources.

Maurício Diogo da Silva: Research Data and Resources.

José de Souza: Writing - review and editing.

Carlos Otávio Damas Martins: Writing - review.

\section{Ethics}

This article is original and contains unpublished material. The corresponding author confirms that all of the other authors have read and approved the manuscript and no ethical issues involved.

\section{References}

ASTM, 2004. AMERICAN SOCIETY OF MECHANICAL ENGINEERS. ASME Section II Part A, Ferrous Materials Specifications. https://bit.ly/3jcS6jW

Araújo, L. C. S. D., Cândido, L. C., Trindade, V. B., \& Porcaro, R. R. (2015). Avaliação da influência de tratamentos térmicos pós-soldagem sobre a microestrutura e propriedades mecânicas de juntas de um aço API 5L X70Q. Soldagem \& Inspeção, 20(2), 171-179.

Barbosa, C., de Barros, S. K., de Cerqueira Abud, I., Do Nascimento, J. L., \& de Carvalho, S. S. (2012). Failure analysis of an aqua tubular boiler tube. Journal of failure analysis and prevention, 12(6), 654-659.

Barbosa Junior, U. (2007). Efeitos dos tratamentos térmicos de normalização, resfriamento rápido e alívio de tensões no aço ASTM A-516 grau 70, utilizado na fabricação de vasos de pressão.
Brandim, A., Sousa, R., \& Alves Jr, C. (2009). Desenvolvimento de um equipamento para ensaio de fadiga térmica. Matéria (Rio de Janeiro), 14(1), 749-758.

Cong, D., Zhou, H., Ren, Z., Zhang, H., Ren, L., Meng, C., \& Wang, C. (2014). Thermal fatigue resistance of hot work die steel repaired by partial laser surface remelting and alloying process. Optics and Lasers in Engineering, 54, 55-61.

Cozza, L. M., Medeiros, J. L. B., Biehl, L. V., Souza, J. D., \& Ferreira Filho, D. (2019). Escolha das Energias de Soldagem para Aplicação na Técnica da Dupla Camada na Soldagem do Aço ASTM 131 Grau AH 36. Soldagem \& Inspeção, 24.

Cozza, L. M., da Silva Junior, M. F., Medeiros, J. L. B., Biehl, L. V., Martins, C. O. D., \& de Souza, J. (2018). Efeito do tratamento térmico de alívio de tensões na microestrutura e tamanho de grão de um aço microligado. Revista Liberato, 19(31), 57-66.

Da Silva, L. L., Mansur, T. R., \& Junior, C. A. C. (2011). Thermal fatigue damage evaluation of a PWR NPP steam generator injection nozzle model subjected to thermal stratification phenomenon. Nuclear engineering and design, 241(3), 672-680.

Duarte, C. A., Espejo, E., \& Martinez, J. C. (2017). Failure analysis of the wall tubes of a water-tube boiler. Engineering Failure Analysis, 79, 704-713.

Gong, Y., Zhong, J., \& Yang, Z. G. (2010). Failure analysis of bursting on the inner pipe of a jacketed pipe in a tubular heat exchanger. Materials \& Design, 31(9), 4258-4268.

Kumar, M. M., Joshna, K., Markendeya, R., \& Rawat, M. S. (2016). Effect of steamside oxidation and fireside corrosion degradation processes on creep life of service exposed boiler tubes. International Journal of Pressure Vessels and Piping, 144, 45-48.

Li, J., Shi, Y., \& Wu, X. (2018). Effect of initial hardness on the thermal fatigue behavior of AISI H13 steel by experimental sand numerical investigations. Fatigue \& Fracture of Engineering Materials \& Structures, 41(6), 1260-1274.

Lim, Y. C., Sanderson, S., Mahoney, M., Wang, Y., Chen, J., David, S. A., \& Feng, Z. (2016). Fabrication of thick multilayered steel structure using A516 Grade 70 by multipass friction stir welding. Science and Technology of Welding and Joining, 21(7), 564-569.

Liu, Q., Wen, H., Zhang, H., Gu, J., Li, C., \& Lavernia, E. J. (2016). Effect of multistage heat treatment on microstructure and mechanical properties of highstrength low-alloy steel. Metallurgical and Materials Transactions A, 47(5), 1960-1974.

Masuyama, F. (2001). History of power plants and progress in heat resistant steels. ISIJ international, 41(6), 612-625. 
Mellouli, D., Haddar, N., Köster, A., \& Ayedi, H. F. (2014). Hardness effect on thermal fatigue damage of hot-working tool steel. Engineering Failure Analysis, 45, 85-95.

Moojen, R. G., Machado, I. G., Mazzaferro, J. A. E., \& Gonzalez, A. R. (2015). Efeitos da taxa de resfriamento na soldagem do aço API 5L-X80. Soldagem \& Inspeção, 20(1), 68-80.

Ribeiro, H. (2001). Soldagem do Aço ASTM A 516 Grau 60 Para Vaso de Pressão Sujeito à Corrosão Sob Tensão. 2001. 91 f (Doctoral dissertation, Dissertação (Mestrado em Ciência e Engenharia de Materiais)-Universidade Federal de Santa Catarina, Florianópolis).

Roa, J. J., Besharatloo, H., Fargas, G., Calvo, J., \& Mateo, A. (2016). Phase transformation under thermal fatigue of high Mn-TWIP steel: Microstructure and mechanical properties. Materials Science and Engineering: A, 677, 431-437.
Shahzad, M., Tayyaba, Q., Manzoor, T., Subhani, T., \& Qureshi, A. H. (2018). The effects of martensite morphology on mechanical properties, corrosion behavior and hydrogen assisted cracking in A516 grade steel. Materials Research Express, 5(1), 016516.

Viswanathan, R., \& Bakker, W. (2001). Materials for ultrasupercritical coal power plants-Boiler materials: Part 1. Journal of materials engineering and performance, 10(1), 81-95.

Zhang, M., Li, L., Fu, R. Y., Krizan, D., \& De Cooman, B. C. (2006). Continuous cooling transformation diagrams and properties of micro-alloyed TRIP steels. Materials Science and Engineering: A, 438, 296-299. 